DOI: $10.33766 / 2524-0323.89 .54-62$

УДК 343.98

\author{
А. Г. Вуйма, \\ ад'юнкт відділу організації \\ освітньо-наукової підготовки \\ Харківського національного \\ університету внутрішніх справ \\ (м. Харків, Україна) \\ e-mail: avuima@ukr.net \\ iDhttps://orcid.org/0000-0002-6215-5361
}

\title{
ПОНЯТТЯ, СУТНІСТЬ ТА ФОРМИ СПЕЦІАЛЬНИХ ЗНАНЬ, ЩО ВИКОРИСТОВУЮТЬСЯ ПІД ЧАС РОЗСЛІДУВАННЯ ВБИВСТВ
}

У статті досліджено питання, що стосуються сутності та форм використання спеціальних знань під час розслідування вбивств. Проаналізовано нормативні положення чинного законодавства та позищії науковців зі вказаного питання. Установлено, що серед науковців відсутня едність у визначенні понять «спеціальні знання» та «форми використання спеціальних знань», що зумовлюе неоднозначність підходів до визначення вказаних понять та їхньої класифікації. Сформульовано поняття «спеціальні знання, що використовуються під час розслідування вбивств» та визначено основні їх форми.

Ключові слова: кримінальне провадження, спеціальні знання, форми використання спеціальних знань, спеціаліст, експерт, розслідування вбивств.

Постановка проблеми. Реформування законодавства, удосконалення юридичної техніки, узагальнення правозастосовчої практики мають сприяти здійсненню правосуддя, у тому числі вирішенню завдань кримінального судочинства 3 урахуванням вимог до його змісту та форми і у відповідності до засад кримінального провадження.

Прогалини в законодавстві пов'язують із проблематикою недосконалості правового забезпечення правосуддя. У зв' язку з цим науковці зобов'язані зосередити свої зусилля на вирішенні практичних завдань, що постають перед працівниками правоохоронних органів.

Протидія злочинам проти життя та здоров'я особи - одне з пріоритетних завдань указаних органів. Умисні вбивства були й залишаються особливо тяжкими злочинами, однак висока міра покарання не $є$ стримуючим фактором щодо зменшення чисельності їх реєстрацій у кримінальній статистиці. Указане обумовлює необхідність здійснення швидкого, повного та неупередженого розслідування, що супроводжувалося б підтвердженням вини особи неспростованими, належними та допустимими доказами, зібраними з мінімальними процесуальними витратами, а також часу, сил і засобів правоохоронних органів.

Здійснення досудового розслідування кримінальних проваджень, розпочатих за фактом умисних убивств, передбачає проведення комплексу дій, спрямованих на виявлення та фіксацію слідів кримінального правопорушення, їx дослідження, a також встановлення обставин, що підлягають доказуванню.

Отже, кримінальні провадження, розпочаті за фактом вбивств, пов'язані із застосуванням спеціальних знань та залученням спеціалістів, співпраця із якими або

(C) Вуйма А. Г., 2020 
носить консультативний характер, або ж призводить до отримання висновку експерта, який Кримінальним процесуальним кодексом України (далі - КПК України) віднесено до одного з самостійних процесуальних джерел доказів.

Аналіз чинного законодавства свідчить про відсутність нормативного визначення поняття «спеціальні знання», «форми спеціальних знань», у зв'язку з чим підтверджується необхідність вирішення вказаного питання, яке, крім того, супроводжується численними дискусіями серед науковців.

Проведений аналіз слідчої та судової практики щодо розслідування умисних вбивств, свідчить про численну кількість проблем організаційно-методичного характеру, що знижують ефективність використання спеціальних знань на стадіі досудового розслідування у вказаних кримінальних провадженнях. Наведені факти обумовлюють актуальність дослідження, необхідність формулювання поняття, визначення сутності та форм застосування спеціальних знань, що використовуються під час розслідування вбивств.

Аналіз останніх досліджень і публікацій. Питання використання спеціальних знань під час розслідування вбивств досить часто досліджувалися науковцями. Так у криміналістичній літературі досить повно висвітлено теоретичні основи дослідження проблем використання спеціальних знань у працях В. П. Бахіна, В. Д. Берназа, Р. С. Бєлкіна, Л. Г. Бордюгова, В. І. Галагана, В. І. Гончаренка, О. О. Закатова, А. В. Іщенка, В. О. Коновалової, І. М. Лузгіна, В. Г. Лукашевича, С. Д. Лук'янчикова, М. В. Салтевського, 3. М. Соколовського, В. В. Тіщенка, В. Ю. Шепітька, М. Г. Щербаковського, А. Р. Шляхова та ін. Окремі питання розвитку та становлення судової експертизи досліджувались такими науковцями, як: Т. В. Авер'янова, Р. С. Бєлкін, А. I. Вінберг, О. М. Ларін, Н. Т. Малаховська, Х. А. Сабіров, М. Г. Щербаковський, B. I. Шиканов та ін. Проте досі не здійснено комплексного дослідження застосування спеціальних знань під час розслідування вбивств.

Указане обумовлює актуальність розроблення наукових положень щодо визначення основних понять та форм використання спеціальних знань, що використовуються під час розслідування вбивств.

Формулювання цілей. Метою статті є формулювання поняття «спеціальні знання, що використовуються під час розслідування вбивств» та визначення форм спеціальних знань, що використовуються під час розслідування вказаної категорії злочинів.

Виклад основного матеріалу. Сьогодні розвитку криміналістики сприяє розширення сфер застосування спеціальних знань у правозастосовчій практищі. Розширюється і спектр науково-технічних та техніко-криміналістичних засобів, що вміло пристосовані спеціалістами до виконання завдань криміналістики та створюють необхідний інструментарій для вирішення завдань кримінального провадження.

Зазначимо, що розкриття в широкому сенсі дефініції поняття «спеціальні знання, що використовуються під час розслідування вбивств» передбачає визначення обсягу тих знань та навичок, які вони включають в себе, кола суб'єктів, що володіють ними, процедурні особливості їх застосування під час розслідування вбивств, що обумовлені відповідними завданнями досудового розслідування. 
Перш ніж перейти до розкриття змісту поняття «спеціальні знання, що використовуються під час розслідування вбивств», пропонуємо розглянути вказане питання з точки зору правової регламентащії та проаналізувати різні позищії науковців щодо визначення даного поняття i, з урахуванням проаналізованих думок, сформулювати власну позищію з цього питання.

Отже, філософія не виділяє як окрему філософську категорію «спеціальні знання», тому це $є$ виключно юридичним поняттям, незважаючи на те, що в чинному законодавстві це поняття не містить своєї нормативної регламентації.

Аналіз положень статей КПК України дає підстави вважати, що спеціальні знання в кримінальному процесуальному аспекті - це наукові, технічні та інші знання, що є підставою для надання володільцми цих знань (експертами та спеціалістами), консультацій або висновків, що стосуються обставин вчинення кримінального правопорушення.

Комплексне дослідження наукових позицій з приводу визначення поняття «спеціальні знання» провів Б. В. Романюк, який присвятив цьому та іншим питанням дисертаційне дослідження. Ним було здійснено класифікацію науковців, які досліджували правову категорію «спеціальні знання» та сформулювали дефініцію вказаного поняття [1, с. 41-45].

Варто зазначити, що першим дав визначення поняття «спеціальні знання» О. О. Ейсман [2, с. 91], який наголошував на тому, що їх опанували меншість («вузьке коло спеціалістів»). Указана позиція наштовхує на висновок про наявність у них відповідної освіти та навичок і підтверджується поглядами В. М. Галкіна [3, с. 8] та 3. М. Соколовського [4, с. 202].

Отож, незважаючи на те, що законодавець не вказав на обов'язкову необхідність наявності в спеціаліста певної освіти, спеціальні знання, на думку вказаних учених, визначаються як сукупність знань та навичок, засвоєних внаслідок отримання відповідної освіти та здійснення професійної діяльності.

Поряд із цим виникає питання про те, чи є слідчий та прокурор носіями спеціальних знань. Так I. В. Рогатюк зазначає, що спеціальні знання притаманні будьяким видам професійної діяльності, і неє винятком галузь юриспруденції [5, с. 723].

Указаний підхід спростовується позищіями О. О. Ейсмана [2, с. 91], Ю. В. Шепітька [6, с. 491-492], М. К. Треушникова [7, с. 192-193], Л. Г. Бордюгова [8, с. 181] та ін. На підтримку позищій останніх, слід зазначити, що, оскільки слідчий та прокурор $\epsilon$ стороною обвинувачення, на них покладено обов'язок доказування, тобто їхнє призначення полягає в збиранні та оцінці доказів і прийнятті відповідних рішень, а не в наданні консультацій чи формулюванні певних висновків на основі наявних спеціальних знань.

Беззаперечно, висловлене не виключає можливості наявності в слідчого, прокурора, судді чи захисника спеціальних знань, однак вони є для них непрофесійними, і володіють вони ними зовсім на іншому рівні, аніж експерти та спеціалісти. Таке застосування має інші процесуальні форми, а результати його застосування мають зовсім інше значення для підсумків досудового розслідування.

Слід зауважити, що правові знання не віднесені законодавцем до категорії спеціальних знань, вказане дає підстави зробити висновок про те, що суб'єкт доказування належить до суб'єктів використання, а не застосування спеціальних знань. 
Отже, виключно експерти та спеціалісти є суб'єктами застосування спеціальних знань у кримінальному провадженні.

Визначаючи межі та сферу знань, які прийнято відносити до спеціальних, варто зазначити, що вітчизняні та зарубіжні вчені, серед яких: Т. В. Авер'янова, О. О. Бондаренко, В. К. Лисиченко, В. В. Циркаль, А. В. Шмонін, М. Г. Щербаковський відносять до спеціальних, знання в галузі конкретної науки і техніки, мистецтва та ремесла $[9$, с. $5 ; 10$, с. $6 ; 11$, с. $18 ; 12$, с. 20; 13, с. 3]. Таке тлумачення змістовної складової поняття «спеціальні знання» підтримується й нами, а також знаходить своє відбиття і в нормативних положеннях, оскільки законодавцем визначено необхідність наявності в особи, яка залучається в якості експерта, наукових, технічних або інших спеціальних знань, до яких можна віднести знання в області мистецтва та ремесла, а також наявність спеціальних знань в особи, яка залучається в якості спеціаліста.

Що стосується процедурних особливостей застосування спеціальних знань у кримінальному провадженні, то тут варто зазначити, що вказана складова може ототожнюватися із формами використання спеціальних знань, що обумовлені конкретними завданнями, які слід розв'язати під час досудового розслідування. Так на необхідності використання спеціальних знань задля вирішення певних процесуальних завдань наголошували В. Г. Гончаренко, В. В. Курдюков, К. В. Легких [14, с. 24].

Проведений аналіз положень чинного законодавства та наукових поглядів учених дозволяє стверджувати, що, розглядаючи вказане поняття крізь призму проблематики його використання виключно в межах методики розслідування вбивств, воно має свої особливості, що знаходять свій прояв як у сфері застосування цих знань, так і в їх основних формах, про які мова піде далі.

Отже, під спеціальними знаннями, що використовуються під час розслідування вбивств, слід розуміти знання в галузі конкретної науки та техніки, засвоєних внаслідок отримання відповідної освіти та здобуті на цій основі, у ході здійснення професійної діяльності, навички, що є підставою для надання суб'єктами застосування цих знань (експертами та спеціалістами), консультацій або висновків, що стосуються обставин вчинення кримінального правопорушення, розпочатого за фактом вбивства, які можуть потягнути за собою настання юридично значущих наслідків для кримінального провадження.

Застосування форм спеціальних знань, під час розслідування вбивств залежить від мети, яку вони переслідують на тій чи іншій стадії кримінального провадження, що обумовлюється завданнями досудового розслідування. Основними цілями, що можуть бути досягнуті під час залучення експертів, - це дослідження об'єктів, явищ та процесів та отримання відповідей на певні питання, що потребують спеціальних знань, а під час залучення спеціалістів, - такі: фіксація слідів кримінального правопорушення, виявлення, вилучення, упакування та збереження речових доказів, попереднє їх дослідження без зміни їх властивостей, ефективна підготовка та проведення процесуальної дії, правильна оцінка вилучених біологічних зразків, щодо їх достатності та придатності, допомога щодо правильного та ефективного застосування науково-технічних та техніко-криміналістичних засобів, отримання консультацій загального характеру щодо події злочину, способу та механізму вчинення злочину, побудова психологічного портрету злочинщя тощо.

Враховуючи проаналізовані позиції науковців [8; 15] традиційно в криміналістищі здійснюеться класифікація форм спеціальних знань, що використовуються 
під час розслідування кримінальних проваджень, на процесуальну та непроцесуальну. Своєю чергою, саме під час розслідування вбивств такі форми мають свої особливості, зважаючи на їх тяжкість та необхідність розв'язання завдань кримінального судочинства.

Отже, до процесуальних форм застосування спеціальних знань, що використовуються під час розслідування вбивств, доцільно віднести такі: залучення експерта до проведення судової експертизи, участь спеціаліста в проведенні процесуальних дій. Своєю чергою, непроцесуальні форми представлені такими, як: консультативно-довідкова діяльність спеціаліста; застосування спеціальних знань і науково-технічних засобів під час проведення окремих тактичних операцій, залучення спеціаліста для надання безпосередньої технічної допомоги (фотографування, складення схем, планів, креслень, відбір зразків для проведення експертизи тощо).

Що стосується такої форми застосування спеціальних знань під час розслідування вбивств, як залучення експерта до проведення судових експертиз, то вона $є$ найбілыш поширеною. Обов'язковість ії проведення забезпечується кримінальним процесуальним законодавством. Усі без винятку кримінальні провадження, розпочаті за фактом вчинення вбивств, передбачають проведення великої кількості судових експертиз. У залежності від способу вчинення вбивств, обставин та фактів, які необхідно встановити під час досудового розслідування, призначаються судово-медичні, судово-психіатричні, молекулярно-генетичні, медико-криміналістичні, судово-балістичні та інші види експертиз.

Найбільш розповсюдженими вважаються судово-медичні експертизи, які передбачають вирішення багатьох питань, серед яких встановлення причин смерті, тяжкості та характеру тілесних ушкоджень виявлених на тілі потерпілого, наявності слідів біологічного походження тощо. Від повноти й грамотності поставлених на вирішення експерта питань відносно виявлених слідів, залежить правильність його висновку, а звідси й повнота та законність розслідування кримінального провадження [16, с. 185].

Кримінальним процесуальним законодавством передбачена й обов' язковість залучення спеціаліста до кримінального провадження, а саме: до проведення деяких процесуальних дій. Наприклад, обов'язково до огляду трупа на місці події залучається спеціаліст (судово-медичний експерт або лікар) [17].

Кримінальним процесуальним законодавством передбачено можливість залучення спеціаліста до проведення процесуальних дій, якщо в цьому виникне потреба або за наявності потреби, що визначається за внутрішнім переконанням слідчого. Так, наприклад, слідчий експеримент доцільно проводити за участю спеціаліста в галузі медицини. Можливість самостійного сприйняття механізму та локалізащії нанесення тілесних пошкоджень, на які вказує особа під час проведення слідчої дії, а також можливість постановки спеціалістом додаткових запитань - усе це є запорукою ефективного проведення додаткової судово-медичної експертизи.

Указана експертиза полягає в дослідженні та реконструкції подій, що відбулися, та направленні на вирішення питань про можливість чи неможливість формування конкретних пошкоджень у конкретній ситуащії [16, с. 186-187]. Тобто сприятиме перевірці слідчих версій та розв'язанні завдань кримінального судочинства. 
Слід зазначити, що слідчий під час розслідування вбивства може залучати спеціаліста для отримання технічної допомоги або надання консультацій. Також можливе використання спеціальних знань під час проведення окремих тактичних операцій, розроблених науковцями. Проведення тих чи інших тактичних операцій під час розслідування вбивств також передбачає використання спеціальних знань, що може бути виражено в довідково-консультативній формі або ж у наданні слідчому безпосередньої технічної допомоги під час застосування науково-технічних і техніко-криміналістичних засобів чи участі в процесуальних діях.

Використання спеціальних знань під час досудового розслідування є частиною його тактичного забезпечення. Необхідність продовження подальших досліджень щодо окресленої проблематики обумовлюється потребою розширення знань працівників правоохоронних органів щодо тактики розслідування вбивств та тактики проведення процесуальних дій, розширенням знань щодо можливостей судових експертиз.

Подалыше дослідження та формулювання теоретичних положень 3 визначених питань сприятимуть наданню належної правової оцінки наявним доказам стороною обвинувачення, а також встановленню необхідного обсягу доказів для притягнення особидо кримінальної відповідальності або закінчення розслідування, тобто для прийняття законного та обгрунтованого рішення в кримінальному провадженні.

Висновки. Підсумовуючи викладене, зазначимо, що в роботі автором сформульовано поняття спеціальних знань, що використовуються під час розслідування вбивств. Визначено основні форми використання спеціальних знань, що поділяються на процесуальну й непроцесуальну та мають свої особливості в контексті розслідування вбивств.

До процесуальних форм застосування спеціальних знань, що використовуються під час розслідування вбивств доцільно відносити такі: залучення експерта до проведення судової експертизи, участь спеціаліста в проведенні процесуальних дій. Непроцесуальні форми представлені такими, як: консультативно-довідкова діяльність спеціаліста; застосування спеціальних знань і науково-технічних засобів під час проведення окремих тактичних операщій, залучення спеціаліста для надання безпосередньої технічної допомоги.

Сформульовані положення мають практичне значення, пропонуємо їх використовувати та враховувати під час розроблення методик розслідування різних видів убивств, з метою забезпечення швидкого та повного досудового розслідування, виконання завдань кримінального судочинства правоохоронними органами.

\section{Використані джерела:}

1. Романюк Б. В. Сучасні теоретичні та правові проблеми використання спеціальних знань у досудовому слідстві: монографія. Київ: НАВС, 2002. 196 с.

2. Эйсман А. А. Заключение эксперта (структура и научное обоснование): монография. Москва: Юридическая литература, 1971. 164 с.

3. Галкин В. М. Средства доказывания в советском уголовном процессе: учебн. пос. / под ред. Н. С. Полевой. Москва: ВНИИСЭ, 1967.50 с.

4. Соколовский 3. М. Понятие специальных знаний. Криминалистика и судебная экспертиза.1969. № 6. С. 200-202. 
5. Рогатюк I. В. Використання спеціальних знань прокурором на стадії порушення кримінальної справи. Криміналістика XXI століття: матеріали міжнар. наук.-практ. конф., м. Харків, 25-26 лист. 2010 р. Харків: Право. 2010. С. 721-723.

6. Шепітько В. Ю. Вибрані твори. Издательская агентство «Апостиль»: избранные труды. Харків, 2010.576 с.

7. Треушников М. К. Судебные доказательства. 3-е изд: монография. Москва: Городец, 2004. 272 с.

8. Бордюгов Л. Г. Применение и использование специальных знаний в уголовном процессе Украины. Теорія тапрактика судовоїекспертизи ікриміналістики. 2014. №14. С. 174-183.

9. Аверьянова Т. В. Белкин Р. С., Корухов Ю. Г., Россинская Е. Р. Энцеклопедия судебной экспертизы. Москва: Юрист, 1999. 552 с.

10. Бондаренко О. О. Процесуальний статус обізнаних осіб та їх правовідносини 3 дізнавачем і слідчим у кримінальному судочинстві: автореф. дис. ... канд. юрид. наук: 12.00.09. Харків, 2004. 19 с.

11. Лисиченко В. К., Циркаль В. В. Использование специальных знаний в следственной и судебной практике: учебн. пособие. Киев: КГУ, 1987. 100 с.

12. Шмонин А. В. Понятие и структура криминалистического обеспечения расследования преступлений. Труды Академии управления МВД России. 2010. № 1 (13). С. 3-8.

13. Щербаковский М. Г. Тактика проведення судових експертиз: конспект лекцій. Харків: ХНУВС, 2004.32 с.

14. Гончаренко В. Г., Курдюков В. В., Легких К. В., Спеціальні знання: генезис, предмет, рівні, форми використання в доказуванні. Вісник Академії адвокатури України. 2007. № 2 (9). C. 22-34.

15. Когутич I. І. Окремі питання сутності та форм використання спеціальних знань у кримінальному провадженні. Вісник Академії адвокатури України. 2015. № 2 (33). С. 112-123.

16. Гусєва В. О. Роль спеціальних медичних знань при розслідуванні злочинів проти працівників правоохоронних органів. Вісник ЛДУВС ім. Е. О. Дідоренка, 2017. № 1. С. 183-188.

17. Кримінальний процесуальний кодекс України: Закон України від 12.04 .2012 № 4651- VI / / БД «Законодавство України» / ВР України. URL: http:/ / zakon.rada.gov.ua/1 aws/show / 4651-17 (дата звернення: 05.02.2020).

\section{References:}

1. Romaniuk, B. V. (2002). Suchasni teoretychni ta pravovi problemy vykorystannia spetsialnykh znan u dosudovomu slidstvi: monohrafiia. Kyiv: NAVS [in Ukrainian].

2. Eysman, A. A. (1971). Zaklyuchenie eksperta (struktura i nauchnoe obosnovanie): monografiya. Moskva: Yuridicheskaya literature. [in Russian].

3. Galkin, V. M. (1967). Sredstva dokazyvaniya v sovetskom ugolovnom protsesse. Moskva: VNIISE. [in Russian].

4. Sokolovskiy, Z. M. (1969). Ponyatie spetsial'nykh znaniy. Kriminalistika i sudebnaya ekspertiza - Criminalistics and Forensic. [in Ukrainian].

5. Rohatiuk, I. V. (2010). Vykorystannia spetsialnykh znan prokurorom na stadii porushennia kryminalnoi spravy. Kryminalistyka XXI stolittia: materialy mizhnar. nauk.-prakt. konf. (Kharkiv, 25-26 lyst. 2010 r.) - Forensic science of the XXI century: Proceedings of the Scientific and Practical Conference (Kharkiv, 25-26 pages. 2010). Kharkiv: Pravo, 721-723. [in Ukrainian].

6. Shepitko, V. Yu. (2010). Vybrani tvory. Xarkiv: Yzdatelskaia ahentstvo «Apostyl». [in Ukrainian].

7. Treushnikov, M. K. (2004). Sudebnye dokazatel'stva. Vol. 3. Moskva: Gorodets. [in Russian]. 
8. Bordyugov, L. G. (2014). Primenenie i ispol'zovanie spetsial'nykh znaniy v ugolovnom protsesse Ukrainy. Teoriia ta praktyka sudovoi ekspertyzy i kryminalistyky - Theory and Practise of Forensic Science and Criminalistics, 14, 174-183. [in Russian].

9. Aver'yanova, T. V., Belkin, R. S., Korukhov, Yu. G., Rossinskaya, E. R. (1999). Entseklopediya sudebnoy ekspertizy. Moskva. [in Ukrainian].

10. Bondarenko, O. O. (2004). Protsesualnyi status obiznanykh osib ta yikh pravovidnosyny $\mathrm{z}$ diznavachem i slidchym $\mathrm{u}$ kryminalnomu sudochynstvi. Extended abstract of candidate's thesis. Kharkiv. [in Ukrainian].

11. Lisichenko, V. K., \& Tsirkal' V. V. (1987). Ispol'zovanie spetsial'nykh znaniy v sledstvennoy i sudebnoy praktike: uchebn. posobie. Kyiv: KG. U [in Ukrainian].

12. Shmonin, A. V. (2010). Ponyatie i struktura kriminalisticheskogo obespecheniya rassledovaniya prestupleniy. Trudy Akademii upravleniya MVD Rossii - Proceedings of the Academy of Management of the Ministry of Internal Affairs of Russia, 1 (13), 3-8. [in Russian].

13. Shcherbakovskyi, M. H. (2004). Taktyka provedennia sudovykh ekspertyz: konspekt lektsii. Kharkiv: KhNUVS. [in Ukrainian].

14. Honcharenko, V. H., Kurdiukov, V. V., Lehkykh, K. V. (2007). Spetsialni znannia: henezys, predmet, rivni, formy vykorystannia v dokazuvanni. Visnyk Akademii advokatury Ukrainy - The Bulletin of the Academy of Advocacy of Ukraine, 2 (9), 22-34. [in Ukrainian].

15. Kohutych, I. I. (2015). Okremi pytannia sutnosti ta form vykorystannia spetsialnykh znan u kryminalnomu provadzhenni. Visnyk Akademii advokatury Ukrainy - The Bulletin of the Academy of Advocacy of Ukraine, 2 (33), 112-123. [in Ukrainian].

16. Husieva, V. O. (2017). Rol spetsialnykh medychnykh znan pry rozsliduvanni zlochyniv proty pratsivnykiv pravookhoronnykh orhaniv. Visnyk LDUVS im. E. O. Didorenka - Bulletin of Luhansk State University of Internal Affairs named after E. O. Didorenko, 1, 183-188. [in Ukrainian].

17. Kryminalnyi protsesualnyi kodeks Ukrainy: Zakon Ukrainy vid 12.04.2012 № 4651-VI. Data onovlennia: 05.02.2020. (2020) URL: http://zakon.rada.gov.ua/laws/show/ 4651-17. [in Ukrainian].

Стаття надіӥшла до редколегіï 16.02.2020

Вуйма А. Г., адъюнкт отдела организации образовательно-научной подготовки Харьковского национального университета внутренних дел (г. Харьков, Украина)

\section{ПОНЯТИЕ, СУЩЬНОСТЬ И ФОРМЫ СПЕЦИАЛЬНЫХ ЗНАНИЙ, КОТОРЫЕ ИСПОЛЬЗУЮТСЯ ПРИ РАССЛЕДОВАНИИ УБИЙСТВ}

Исследованы проблемные вопросы о сущности и формах использования специальных знаний в уголовном производстве в целом и при расследовании убийств в частности. Проанализированы нормативные положения действующего законодательства и позиции ученых по указанному вопросу. Установлено также, что среди ученых отсутствует единство в определении понятий «специальные знания» и «формы использования специальных знаний», что приводит к неоднозначности подходов к определению указанных понятий и их классификации. Сформулировано понятие «специальные знания, используемые при расследовании убийств» и определены основные их формы. 
Ключевые слова: уголовное производство, специальные знания, формы использование специальных знаний, специалист, эксперт, расследование убийств.

\author{
Vuima A., \\ Adjunct Department of the organization \\ educational and scientific training \\ of Kharkiv National University \\ of Internal Affairs \\ (Kharkiv, Ukraine)
}

\title{
CONCEPTS, ESSENCE AND FORMS OF SPECIAL KNOWLEDGE USED IN THE CURRENT INVESTIGATION
}

The article deals with problematic issues regarding the use of specialized knowledge in homicide investigations, legislative acts are analyzed. The purpose of the article is to formulate the notion of "special knowledge used in the investigation of killings", to disclose their essence and to define the forms of special knowledge used in the investigation of the specified category of crimes. The author has described the existing in science point of views on understanding of concept of the special knowledge, has pointed out their defects and undertook an attempt to give the determination to this concept. On the basis of the scientists' opinions, the concept of special knowledge is formulated. Publications, which made the beginning of this concept research, have being indicated. The author proved that special attainments in criminal proceedings belong to experts and specialists. The author also substantiated the impossibility of assigning the investigator and the prosecutor to the category of subjects identified as possessors of specialized knowledge. It is determined that to this date the single systematization of forms of application of the special knowledge does not exist.

The author draws attention to the fact that the results of the use of special knowledge are one of the unique ways of obtaining valuable evidential information, and its conclusions are an important source of evidence.

Based on the opinion analysis of criminalistic scientists, forms of special knowledge use divided according to different criteria into procedural and non-procedural. The most commonly used forms are indicated, among them: appointment of forensic examinations, involvement of specialist for performing investigative actions, consulting and reference, auditing and monitoring of records. The author has identified and analyzed the mandatory cases for the appointment of forensic expertise and involvement of specialists in procedural actions.

Keywords: criminal proceeding, special knowledge, form of application of the special knowledge, specialist, expert, homicide investigation. 